\title{
Green Production of Cladribine by Using Immobilized 2'-Deoxyribosyltransferase from Lactobacillus delbrueckii Stabilized through a Double Covalent/Entrapment Technology
}

\author{
Cintia Wanda Rivero ${ }^{1,2, *}$, Natalia Soledad García ${ }^{1}$, Jesús Fernández-Lucas ${ }^{3,4} \oplus$, Lorena Betancor ${ }^{5}$, \\ Gustavo Pablo Romanelli ${ }^{6}$ and Jorge Abel Trelles ${ }^{1,2, *}$ \\ 1 Laboratory of Sustainable Biotechnology (LIBioS), National University of Quilmes, \\ Bernal B1876BXD, Argentina; garcia.nataliansg@gmail.com \\ 2 National Scientific and Technical Research Council (CONICET), \\ C1425FQB Ciudad Autónoma de Buenos Aires, Argentina \\ 3 Applied Biotechnology Group, Biomedical Science School, Universidad Europea de Madrid, \\ 28670 Villaviciosa de Odón, Spain; JESUS.FERNANDEZ2@universidadeuropea.es \\ 4 Research Group in Natural and Exact Sciences, GICNEX, Universidad de la Costa, CUC, \\ Barranquilla 080002, Colombia \\ 5 Biotechnology Laboratory, Faculty of Engineering, Universidad ORT Uruguay, \\ Montevideo 11100, Uruguay; betancor@fi365.ort.edu.uy \\ 6 Center for Research and Development in Applied Sciences, National University of La Plata, \\ La Plata B1900AJK, Argentina; gpr@quimica.unlp.edu.ar \\ * Correspondence: crivero@unq.edu.ar (C.W.R.); jtrelles@unq.edu.ar (J.A.T.)
}

check for updates

Citation: Rivero, C.W.; García, N.S.; Fernández-Lucas, J.; Betancor, L.; Romanelli, G.P.; Trelles, J.A. Green Production of Cladribine by Using Immobilized 2'-Deoxyribosyltransferase from Lactobacillus delbrueckii Stabilized through a Double Covalent/Entrapment Technology. Biomolecules 2021, 11, 657. https://doi.org/10.3390/biom11050657

Academic Editor: Yunjun Yan

Received: 30 March 2021

Accepted: 23 April 2021

Published: 29 April 2021

Publisher's Note: MDPI stays neutral with regard to jurisdictional claims in published maps and institutional affiliations.

Copyright: (c) 2021 by the authors. Licensee MDPI, Basel, Switzerland. This article is an open access article distributed under the terms and conditions of the Creative Commons Attribution (CC BY) license (https:/ / creativecommons.org/licenses/by/ $4.0 /)$.

\begin{abstract}
Nowadays, enzyme-mediated processes offer an eco-friendly and efficient alternative to the traditional multistep and environmentally harmful chemical processes. Herein we report the enzymatic synthesis of cladribine by a novel 2'-deoxyribosyltransferase (NDT)-based combined biocatalyst. To this end, Lactobacillus delbrueckii NDT ( $L d \mathrm{NDT}$ ) was successfully immobilized through a two-step immobilization methodology, including a covalent immobilization onto glutaraldehydeactivated biomimetic silica nanoparticles followed by biocatalyst entrapment in calcium alginate. The resulting immobilized derivative, SiGPEI 25000-LdNDT-Alg, displayed $98 \%$ retained activity and was shown to be active and stable in a broad range of $\mathrm{pH}(5-9)$ and temperature $\left(30-60{ }^{\circ} \mathrm{C}\right)$, but also displayed an extremely high reusability (up to 2100 reuses without negligible loss of activity) in the enzymatic production of cladribine. Finally, as a proof of concept, SiGPEI 25000-LdNDT-Alg was successfully employed in the green production of cladribine at mg scale.
\end{abstract}

Keywords: biomimetic silica; enzyme immobilization; glutaraldehyde; entrapment; calcium alginate; antineoplastic drug

\section{Introduction}

Cladribine (2-chloro-2'-deoxy- $\beta$-D-adenosine) is an FDA approved drug for the treatment of hairy cell leukemia [1]. It has also recently received EMA approval for relapsingremitting multiple sclerosis (RRMS) treatment [2].

Traditionally, cladribine is synthesized by chemical methods that require multiple reaction steps, the use of organic solvents, and removal of protecting groups, causing the accumulation of racemic mixtures that affect further purification [3,4]. However, the use of bioprocesses catalyzed by whole cells or enzymes has emerged as a green synthetic alternative with multiple advantages, such as mild reaction conditions, high efficiency, and regio-, stereo-, enantioselectivity [5-15]. In this sense, the transglycosylation reaction catalyzed by nucleoside phosphorylases (NPs) or 2'-deoxyribosyltransferases (NDTs) is the most studied biocatalytic methodology for the synthesis of nucleoside analogs (NAs) up to date [5-15]. 
Several factors such as low operational stability, short availability, the high cost of recombinant enzymes, and difficult recovery have hindered the use of enzymes for industrial applications [16]. Some of these drawbacks can be overcome by the immobilization of the biocatalyst, which can improve enzyme properties, such as activity and specificity. Additionally, it enables an easy product recovery and also increases the half-life of enzymes, and allows for biocatalyst reusability [17-20].

In this regard, the use of silica-based matrixes in enzyme immobilization has started to attract interest due to its nontoxicity, excellent biocompatibility, and stability over a wide range of pressure, $\mathrm{pH}$, and temperature [21-24]. Under mild conditions silica formation in biogenic systems, is mediated by cationic proteins and peptides, but it can also be mediated by a range of simple polyamine molecules $[25,26]$. Furthermore, entrapment methods are also widely used for enzyme immobilization, and one of the most common supports is alginate, a natural anionic biopolymer usually obtained from brown seaweed [27]. Because of its biocompatibility, nontoxicity, and relatively low cost, alginate has been extensively used for pharmaceutical and medical applications [28,29].

Herein we show the development of a highly stabilized biocatalyst for the production of cladribine based on immobilization of 2'-deoxyribosyltransferase from Lactobacillus delbrueckii (LdNDT) on modified silica-based matrixes through a two-step immobilization methodology, including a covalent immobilization onto glutaraldehyde-activated biomimetic silica nanoparticles followed by biocatalyst entrapment in calcium alginate (Figure 1). Biochemical characterization of the immobilized derivatives, including the effect of $\mathrm{pH}$ and temperature on enzyme activity and stability, as well as the biocatalysts reusability, led us to select an optimal biocatalyst for further scale-up. Finally, the developed biocatalyst was successfully employed in the production of cladribine at mg scale $(1.8 \mathrm{mg})$ using a batch system with an airlift column. 


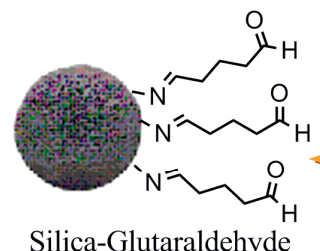

Glutaraldehyde

$$
{ }_{H}
$$

(SiG)
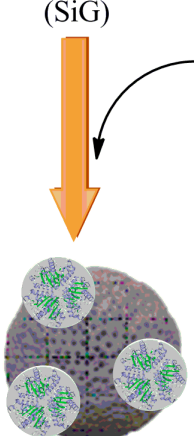

Silica-Glutaraldehyde$L d$ NDT (SiG-LdNDT)
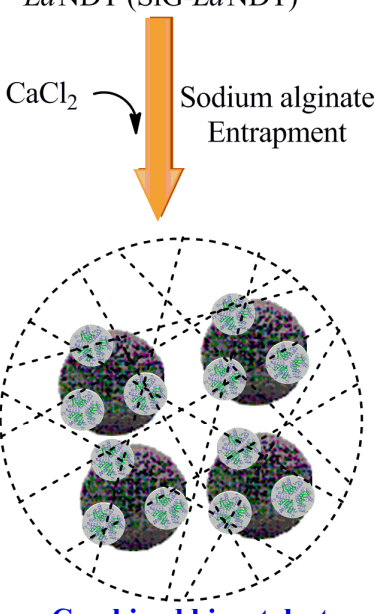

Combined biocatalyst (SiG-LdNDT-Alg)

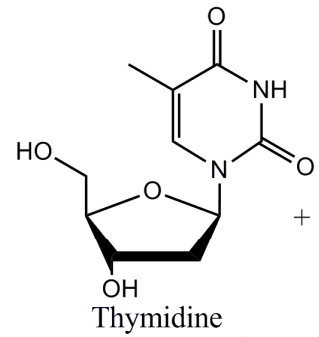

Silica (Si)

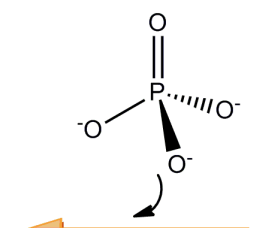

$\mathrm{HO}_{\mathrm{Hi}^{\prime}}^{\mathrm{HOH}}{ }_{\mathrm{OH}}^{\mathrm{OH}}$

Hydrolyzed TMOS

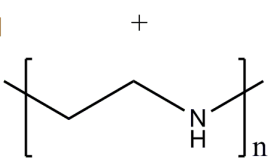

Polyethyleneimine<smiles>Nc1nc(Cl)nc2[nH]cnc12</smiles>

2-Chloroadenine

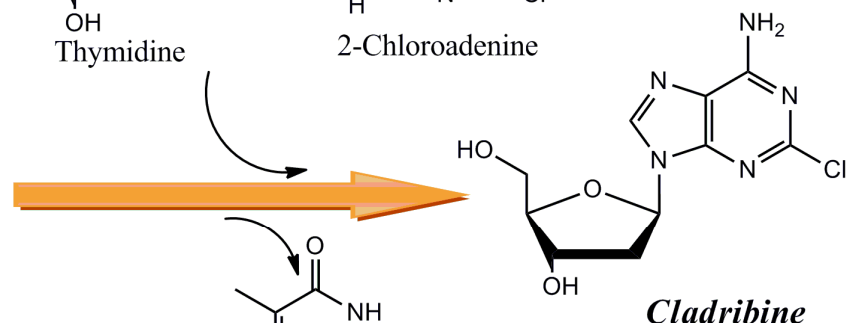

Cladribine

Thymine

Figure 1. Schematic representation of the combined immobilization procedure, carried out in this work to obtain cladribine, through the development of a highly stabilized biocatalyst. TMOS: tetramethylorthosilicate, PEI: Polyethyleneimine and LdNDT: Recombinant NDT from Lactobacillus delbrueckii.

\section{Materials and Methods}

\subsection{Materials}

Nucleosides and bases were purchased from Sigma-Aldrich (USA). Culture media compounds were obtained from Britania S.A. (CABA, Argentina). Polyethyleneimine (PEI, MW 1.200-1.300, 25.000 and 70.000) was from Sigma Aldrich (St. Louis, MI, USA). The HPLC grade solvents used were from Sintorgan S.A. (Villa Martelli, Argentina). Cyanogen bromide (CNBr) activated Sepharose beads werepurchased from GE-Healthcare (Uppsala, Sweden), tetramethylorthosilicate (TMOS) was purchased from Merck S.A. (Gernsheim, Germany) and sodium alginate was from Saporiti S.A.C.I.F.I.A (CABA, Argentina). All other reagents were of analytical grade.

\subsection{Production of $L d N D T$}

Type II NDT from Lactobacillus delbrueckii (LdNDT) was produced and purified as previously reported $[30,31]$. 


\subsection{Standard Activity Assay for LdNDT}

Biotransformation of cladribine from thymidine (Thd) and 2-chloroadenine (2-ChlAde) was selected as standard reaction to evaluate enzymatic activity. To this effect, $10 \mu \mathrm{g}$ $L d$ NDT (free or immobilized) were added to solution containing $1.5 \mathrm{mM}$ Thd and $0.5 \mathrm{mM}$ 2-ChlAde in $25 \mathrm{mM}$ tris- $\mathrm{HCl}$ buffer, $\mathrm{pH} \mathrm{7.0,} \mathrm{at} 50{ }^{\circ} \mathrm{C}$ and $200 \mathrm{rpm}$ shaking speed. The enzyme was inactivated by adding $100 \mu \mathrm{L}$ of cold methanol in an ice-bath and heating for $5 \mathrm{~min}$ at $100{ }^{\circ} \mathrm{C}$. After centrifugation at 10,000 rpm for $3 \mathrm{~min}$, the samples were halfdiluted with water and frozen at $-20{ }^{\circ} \mathrm{C}$. Nucleoside production was analyzed using HPLC to measure quantitatively the reaction products, as described below. All of the determinations were carried out in triplicate and the maximum error was less than $5 \%$. In such conditions, one unit of enzyme (U) was defined as the amount $(\mathrm{mg})$ of enzyme that produces $1 \mu \mathrm{mol} / \mathrm{min}$ (IU) of cladribine.

\subsection{LdNDT Immobilization}

TMOS was hydrolyzed with $1 \mathrm{mM} \mathrm{HCl}$ in 157:1000 $(v / v)$ ratio. $10 \%(v / v)$ solutions of PEI (Mw 1.200-1.300, 25.000 or 70.000, depending on the case) were prepared in $100 \mathrm{mM}$ sodium phosphate buffer ( $\mathrm{pH} 8.0)$.

\subsubsection{Biomimetic Silica Entrapment (SiBio)}

For $L d \mathrm{NDT}$ entrapment in SiBio, $2.5 \mathrm{~mL}$ of freshly hydrolyzed TMOS, $2.5 \mathrm{~mL}$ of a PEI solution $(10 \%, v / v)$, and $L d \mathrm{NDT}$ solution containing $230 \mu \mathrm{g} / \mathrm{mL}$ were mixed. Instant precipitation and subsequent enzyme entrapment wereobserved. The preparation was centrifuged at $5000 \mathrm{rpm}$ for $10 \mathrm{~min}$ and washed with $\mathrm{NaCl} 500 \mathrm{mM}$ to eliminate proteins ionically adsorbed to nanoparticle surface. Then, the SiBio biocatalyst was washed three times with $25 \mathrm{mM}$ sodium phosphate buffer (pH 7.0) until use.

\subsubsection{Immobilization on Modified Biomimetic Silica Nanoparticles}

To obtain biomimetic silica nanoparticles, $2.5 \mathrm{~mL}$ of freshly hydrolyzed TMOS was added to $2.5 \mathrm{~mL}$ of a PEI solution $(10 \%, v / v)$ and the preparation was mixed. The nanoparticles formed were centrifuged at $5000 \mathrm{rpm}$ for $10 \mathrm{~min}$ and washed with $25 \mathrm{mM}$ sodium phosphate buffer ( $\mathrm{pH} 7.0)$.

To obtain glyoxyl modified biomimetic silica support (SiGlx), $1 \mathrm{~g}$ of crude silica was mixed in $0.28 \mathrm{~mL}$ of distilled water. Then, $32 \mathrm{mg}$ of sodium hydroxide $(\mathrm{NaOH})$ previously dissolved in $0.5 \mathrm{~mL}$ of distilled water was added and subsequently $14 \mathrm{mg}$ of solid $\mathrm{BH}_{4} \mathrm{Na}$ was incorporated. Afterwards, $0.35 \mathrm{~mL}$ of glycidol was added drop by drop, leaving it for $16 \mathrm{~h}$ at room temperature with gentle agitation. Finally, reactive groups were activated by incubation for $2 \mathrm{~h}$ at room temperature with $15 \mathrm{~mL}$ of $10 \mathrm{mM} \mathrm{NaIO}_{4}$ solution. It was recovered by centrifugation at $5000 \mathrm{rpm}$ for $10 \mathrm{~min}$, rinsed with distilled water, and finally with $25 \mathrm{mM}$ sodium phosphate buffer ( $\mathrm{pH}$ 7.0). LdNDT immobilization on SiGlx, was carried out at $4{ }^{\circ} \mathrm{C}$ using $0.5 \mathrm{~g}$ of support and $10 \mathrm{~mL}$ of enzyme in carbonate buffer $(0.1 \mathrm{M} ; \mathrm{pH} 10.0)$. The mixtures were centrifuged for $15 \mathrm{~min}$ at $5000 \mathrm{rpm}$ and the supernatant was recovered for protein quantification several times to determine the percentage of immobilization [32]. Finally, residual reactive groups were inactivated by addition of $\mathrm{BH}_{4} \mathrm{Na}(1 \mathrm{mg} / \mathrm{mL})$.

Glutaraldehyde-modified biomimetic silica nanoparticles ( $\mathrm{SiG}$ ) were synthesized using, $1 \mathrm{~g}$ silica which was incubated with $20 \mathrm{~mL}$ of a glutaraldehyde solution $(15 \%, v / v$ in $25 \mathrm{mM}$ sodium phosphate buffer, $\mathrm{pH} 7.0$ ) at $25^{\circ} \mathrm{C}$ and agitation by inversion for overnight. The SiG support was centrifuged and washed three times with $25 \mathrm{mM}$ sodium phosphate buffer (pH 7.0). For $L d \mathrm{NDT}$ immobilization, $0.5 \mathrm{~g}$ of $\mathrm{SiG}$ was mixed with $10 \mathrm{~mL}$ of enzyme solution in $25 \mathrm{mM}$ sodium phosphate buffer $(\mathrm{pH} 7.0)$ and incubation was performed at $4{ }^{\circ} \mathrm{C}$. The mixtures were centrifuged for $15 \mathrm{~min}$ at $5000 \mathrm{rpm}$ and the supernatant was recovered for protein quantification several times to determine the percentage of immobilization [32].

To carry out $L d \mathrm{NDT}$ immobilization by adsorption on the silica nanoparticles surface and subsequently coating them with glutaraldehyde (SiAdsG), $0.5 \mathrm{~g}$ of crude silica was 
incubated with $10 \mathrm{~mL}$ of enzyme solution in $25 \mathrm{mM}$ sodium phosphate buffer (pH 7.0) at $4{ }^{\circ} \mathrm{C}$ for $16 \mathrm{~h}$. After incubation, the derivative was recovered by centrifugation and mixed with glutaraldehyde $0.5 \%(v / v)$ in $25 \mathrm{mM}$ sodium phosphate buffer $(\mathrm{pH} 7.0)$ at $25^{\circ} \mathrm{C}$ for $1 \mathrm{~h}$ to allow cross-linking reaction.

\subsubsection{Cyanogen Bromide (CNBr) Immobilization}

For CNBr immobilization, $10 \mathrm{~mL}$ of purified $L d \mathrm{NDT}$ in $25 \mathrm{mM}$ sodium phosphate buffer ( $\mathrm{pH}$ 7.0) were added to $0.5 \mathrm{~g}$ of previously activated support. The mixture was stirred gently for $2 \mathrm{~h}$, at $4{ }^{\circ} \mathrm{C}$ and after that, the percentage of immobilization was calculated [32]. Then, the supernatant was removed and $20 \mathrm{~mL}$ of ethanolamine (1 M, pH 8.0) wasadded for $2 \mathrm{~h}$ to block the cyanogen bromide groups on the support. Finally, the derivative was washed twice with $25 \mathrm{mM}$ sodium phosphate buffer (pH 7.0) and stored at $4{ }^{\circ} \mathrm{C}$ until use.

\subsection{Biochemical Characterization of SiG $G_{P E I 25000-L d N D T \text { Derivative }}$}

To assay the effect of $\mathrm{pH}$ and temperature on biocatalyst activity, $33 \mathrm{mg} \mathrm{SiGPEI25000^{- }}$ $L d$ NDT $(10 \mu \mathrm{g}$ of immobilized $L d \mathrm{NDT}$ ) were incubated with $1 \mathrm{~mL}$ of reaction solution containing $0.5 \mathrm{mM}$ 2-ChlAde and $1.5 \mathrm{mM}$ Thd at $200 \mathrm{rpm}$ during different times. The effect of $\mathrm{pH}$ on SiGPEI25000-LdNDT activity was tested using sodium acetate (pH 5.0) and tris$\mathrm{HCl}$ ( $\mathrm{pH} 7.0$ and 9.0), as reaction buffers $(25 \mathrm{mM}$ ). Moreover, the temperature profile was assessed across a $30-60{ }^{\circ} \mathrm{C}$ interval.

\subsection{Derivative Entrapment in Alginate}

There were $0.33 \mathrm{~g}$ SiGPEI25000-LdNDT derivative added to a $1 \mathrm{~mL}$ sodium alginate $6 \%$ $(p / v)$ in physiologic solution. The mixture was added drop-wise to a $30 \mathrm{~mL}$ stirred solution of $0.3 \mathrm{M} \mathrm{CaCl}_{2}$ and incubated for $15 \mathrm{~min}$ at $25^{\circ} \mathrm{C}$ [33]. The formed beads, SiGPEI25000$L d$ NDT-Alg, were filtered and washed twice with $25 \mathrm{mM}$ tris-HCl buffer (pH 7.0).

\subsection{Surface Morphology Study}

Scanning electron microscopy (SEM) with energy dispersive X-ray spectroscopy (EDX) analysis was made with a Philips 505 scanning electron microscope using an accelerating voltage of $25 \mathrm{eV}$. The solid samples were metalized with gold. The chemical composition of the materials was analyzed by $\mathrm{X}$-ray scattering.

\subsection{Thermal Inactivation and $p H$ Stability}

To study the thermal stability, the obtained biocatalysts $\mathrm{SiG}_{\mathrm{PEI} 25000}-L d \mathrm{NDT}$ and $\mathrm{SiG}_{\mathrm{PEI} 25000-}$ $L d$ NDT-Alg were incubated at 30,50 and $60^{\circ} \mathrm{C}$ in $25 \mathrm{mM}$ tris- $\mathrm{HCl}$ buffer ( $\left.\mathrm{pH} 7.0\right)$, for different times during periods superior than $3000 \mathrm{~h}$.

In a similar way, the effect of $\mathrm{pH}$ on biocatalysts stability was determined. SiGPEI25000$L d$ NDT and SiGPEI25000- $L d$ NDT-Alg were incubated at $30^{\circ} \mathrm{C}$ in the presence of $25 \mathrm{mM}$ sodium acetate buffer ( $\mathrm{pH}$ 5), $25 \mathrm{mM}$ tris- $\mathrm{HCl}$ buffer ( $\mathrm{pH}$ 7), or $25 \mathrm{mM}$ tris- $\mathrm{HCl}$ buffer $(\mathrm{pH} 9)$ at different times during $3300 \mathrm{~h}$.

Residual activity in cladribine biosynthesis as previously described was determined. Protein release was evaluated by Bradford and the amount of protein detected in supernatant was determined.

\subsection{Storage Stability and Operational Reusability}

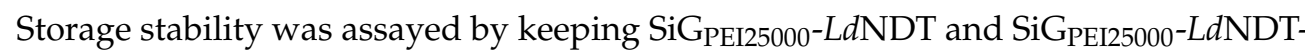
Alg biocatalysts in $25 \mathrm{mM}$ tris- $\mathrm{HCl}$ buffer (pH 7.0) at $4{ }^{\circ} \mathrm{C}$ and determining its ability in cladribine biosynthesis for 300 days, as previously described.

Furthermore, the reusability of SiGPEI25000-LdNDT and SiGPEI25000-LdNDT-Alg was evaluated through successive standard cladribine biotransformations until $50 \%$ of initial activity loss or matrix integrity loss. Each reuse was performed for 15 min under previously optimized conditions. 


\subsection{Bioprocess Scale-Up}

A scale-up bioprocess was assayed, for cladribine biosynthesis, using a batch system with an airlift column (H: $120 \mathrm{~mm}, \mathrm{D}: 3.4 \mathrm{~mm}$ ). Biosynthesis was carried out using $0.3 \mathrm{~g}$ of

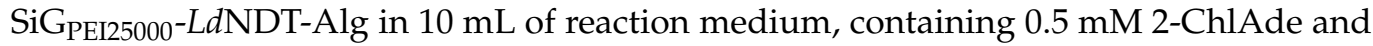
$1.5 \mathrm{mM}$ Thd in $25 \mathrm{mM}$ tris- $\mathrm{HCl}$ buffer ( $\mathrm{pH} 7.0)$ at $30^{\circ} \mathrm{C}$.

\subsection{Analytical Methods}

Cladribine biosynthesis was quantitatively monitored by HPLC (Dionex, Ultimate 3000, Thermo Scientific) equipped with a UV detector (UV/Vis 156, Dionex) using a Nucleosil 10 C18 100A column $(10 \mu \mathrm{m}, 300 \mathrm{~mm} \times 4 \mathrm{~mm})$. An isocratic mobile phase of water/methanol $(90: 10, v / v)$ and a flow rate of $1.5 \mathrm{~mL} / \mathrm{min}$ were used and evaluated at $265 \mathrm{~nm}$. Retention times of thymine (Thm), Thd, 2-ChlAde, and 2-ChlAdo (cladribine) were $3.3,5.1,12.2$, and $26.8 \mathrm{~min}$, respectively. Cladribine was characterized in multiple reaction monitoring (MRM) mode using an AB5000 triple quadrupole mass spectrometer (Applied Biosystems, San Jose, CA) equipped with an electrospray ionization source (ESI). The ion ESI-mass spectrum of the product showed the peak of 2-ChlAdo $[\mathrm{M}+\mathrm{H}]^{+}: 286$, which were consistent with the molecular mass described for the product (average mass: 285.6873 and monoisotopic mass: 285.0629). The software Xcalibur 1.3 was used.

\subsection{Molecular Modeling}

As previously described type II NDT from Lactobacillus leichmannii, LlNDT (PDB id 1F8X) was selected as structural template for homology modeling ( $98 \%$ of identity) employing Swiss-Model server. Missing amino acids in all subunits were accomplished throughout interactive molecular graphics program PyMOL [34]. Thd was manually docked into LdNDT active site by means of structural best-fit superposition onto the former nucleoside. The system was prepared and energy progressively refined in TIP3P explicit solvent according to [35]. Moreover, $30 \mathrm{~ns}$ of unrestrained molecular dynamics simulation were performed to achieve the most suitable $L d$ NDT-Thd complex, according to a previously described protocol [36]. Resulting trajectories were processed by module implemented in AMBER16 [37].

\subsection{Sustainability Impact}

Green chemical parameters of the described bioprocesses were calculated to demonstrate mass utilization efficiency. The environmental factor (E-Factor) is a measure of the industrial environmental impact. Carbon efficiency (C-efficiency) and atom economy (A-economy) are designed as parameters to evaluate the efficiency of synthetic reactions. All the above-mentioned parameters were calculated as previously described [38].

\section{Results and Discussion}

\subsection{Enzyme Immobilization Screening}

As previously described, $L d \mathrm{NDT}$ is able to recognize many different purine analogs and has high activity across a wide range of temperatures [31]. However, the use of soluble enzymes in biocatalysis has many limitations because of the high cost of recombinant enzymes, low stability, and the complicated downstream processing to recover the enzyme from the reaction media [39]. Based on this, enzyme immobilization emerges as an alternative to overcome all these drawbacks, favoring product recovery and improving biocatalyst reusability and stability. Therefore, $L d N D T$ was selected as a candidate for further immobilization studies.

The use of silica nanoparticles as a support for enzyme immobilization has attracted considerable attention due to their biocompatibilty, low toxicity, and scalable availability. The silica synthesized by diatoms is an interesting starting point for enzyme immobilization since it occurs under mild conditions compatible with biological activity [26,40]. Biomimetic or bio inspired silica is thein vitrosilica formation through reactions derived or similar to 
those occurring in vivo. It produces nanostructured particles and is carried out at close to neutral $\mathrm{pH}$ and room temperature under aqueous conditions.

With this aim, $L d$ NDT immobilization was assayed onto different biomimetic aminated silica supports using several methodologies, such as biocatalyst entrapment on biomimetic silica matrix (SiBio) [41], covalent immobilization onto silica nanoparticles functionalized with glyoxyl (SiGlx) [10,42,43] or glutaraldehyde (SiG) [44-46], and ionic adsorption [47] onto biomimetic silica nanoparticles followed by glutaraldehyde cross-linking (SiAdsG) $[42,43,46]$. Moreover, as a control of the immobilization process, LdNDT was also immobilized onto agarose activated with cyanogen bromide (CNBr) [48], a well-known support used for enzyme immobilization.

Due to the low immobilization percentages, together with a significant loss of catalytic activity observed when $L d \mathrm{NDT}$ was immobilized in SiBio and SiGlx; the SiBio-LdNDT and SiGlx-LdNDT derivatives were discarded after the initial screening (data not shown). In contrast, the derivatives obtained after $L d \mathrm{NDT}$ immobilization on SiG, SiAdsG and CNBr supports (SiG-LdNDT, SiAdsG-LdNDT, and CNBr-LdNDT) displayed high immobilization percentages (50-100\%), and also, a high retained activity (around 70-100\%).

Since soluble $L d N D T$ was stable at alkaline $\mathrm{pH}$ values for a period of $30 \mathrm{~h} \mathrm{[30],} \mathrm{it} \mathrm{was}$ not expected that $\mathrm{pH} 10$ incubation onto silica functionalized with glyoxyl (SiGlx) led to this drastic loss of activity. So, too deep into this unexpected side-effect and to try to understand the effect of multipoint binding on enzyme activity, different 3D homology models of both, LdNDT and complexed with Thd, were built.

As previously described, LdNDT is a homo-hexamer in solution, organized as a trimer of dimers [30,31]. Each dimer displays two active sites formed by different amino acids of both monomers. However, after seeing the exposed surface of lysines residues, we could observe that there are two amino acids (Lys 48 and 62) present in a catalytic loop (Figure 2). This highly mobile and flexible loop act as active site flap over, shielding it from surrounding environment [6,7], and also contains a glutamine residue (Gln46) which hydrogen bonds to $\mathrm{N}^{\prime}$ and $\mathrm{O}^{\prime}$ from pyrimidine moiety.

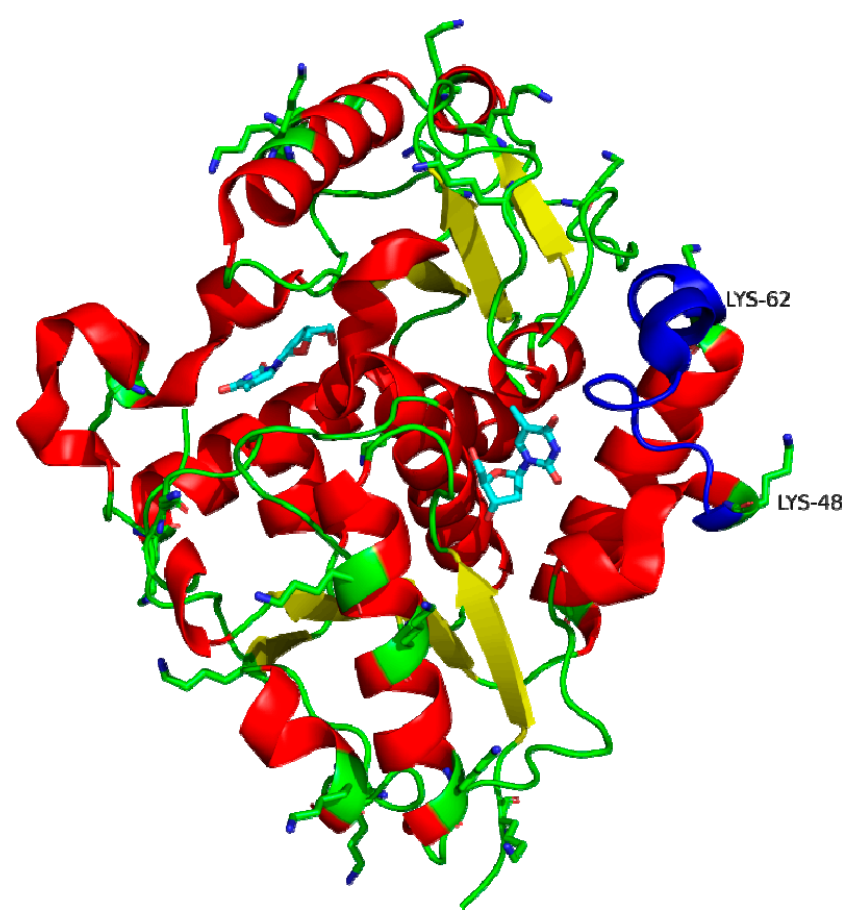

Figure 2. Overall representation of surface exposed Lys residues (atom colored sticks) in LdNDT active site complexed with Thd (atom colored sticks). The cartoon representation is used for simplicity and ease of visualization. The catalytic loop region (amino acids 48 up to 62) is highlighted in blue. The figure has been prepared with PyMOL [34]. 
In this context, results reported by the $\mathrm{H}++$ protonation predictor program (http: / / biophysics.cs.vt.edu/H++, accessed on 24 March 2021) (Table S1, Supplemental Material) [48-50] displayed that both, Lys 48 and 62, are deprotonated at $\mathrm{pH}$ values required for immobilization on glyoxyl agarose ( $\mathrm{pH} 10-11)$. As a consequence, they can be involved in the covalent linkages, reducing the mobility and flexibility of this catalytic loop and avoiding the proper binding orientation of pyrimidine ring during the catalytic process, which leads to a pronounced loss of activity.

In contrast, covalent immobilization onto $\mathrm{SiG}$ nanoparticles or $\mathrm{CNBr}$ agarose beads displayed negligible effects on enzyme activity. According to Table S1, a pKa $=7$ is deduced for $\mathrm{N}$-terminus, which is lined with an unipunctual immobilization through $\mathrm{N}$-terminus under immobilization conditions required for immobilization in $\mathrm{SiG}$ nanoparticles or $\mathrm{CNBr}$ agarose ( $\mathrm{pH}$ 7.0) [48-51]. Moreover, as shown in Table S1, Lys 48 and 62 residues are not deprotonated at $\mathrm{pH} 7.0$, which prevents the immobilization through these surface Lys residues, which avoids the distortion of the active site architecture [6,7]. Since the $\mathrm{N}$-terminus is not involved in catalysis in $\mathrm{LdNDT}$, and it is far from the active site, a high activity loss was not expected for the unipunctual immobilization through $\mathrm{N}$-terminus (as corroborated for CNBr-LdNDT, SiG-LdNDT derivatives).

\subsection{Synthesis of SiG Nanoparticles Using Several PEI Sizes}

It is known that the amount of PEI adsorbed to the surface is known as the polymer coating surface. The higher the molecular weight of the coating polymers, the larger coating nanoparticle surface is obtained and a stabilizing force of the silica is achieved [52]. Therefore, the obtained silica nanoparticles using smaller PEI Mw could be less stabilizing than those obtained with PEI of a larger size. Based on this, PEI of three different sizes (Mw 1.200-1.300, 25.000 , and 70.000) were evaluated in the synthesis of glutaraldehyde-activated biomimetic silica nanoparticles, obtaining SiGPEI1200-1300, $\mathrm{SiG}_{\mathrm{PEI} 25000}$ and $\mathrm{SiG}_{\mathrm{PEI} 70000}$ supports.

The immobilization of $L d N D T$ was then tested using the obtained supports and the biocatalytic capacity in cladribine biosynthesis of the derivatives SiGPEI1200-1300-LdNDT, $S_{\text {SiGEI25000- }} L d \mathrm{NDT}$, and SiGPEI70000- $L d \mathrm{NDT}$ was compared with soluble $L d \mathrm{NDT}$ and CNBrLdNDT (Table 1).

Table 1. Covalent immobilization of $L d N D T$ onto different supports.

\begin{tabular}{|c|c|c|c|}
\hline Biocatalyst & Immobilization (\%) & $\begin{array}{l}\text { Specific Activity } \\
(\text { IU } / \mathrm{mg})^{a}\end{array}$ & Retained Activity (\%) \\
\hline \multicolumn{4}{|l|}{$L d \mathrm{NDT}$} \\
\hline $230 \mu \mathrm{g}^{\mathrm{b}}$ & 70 & $2.9 \pm 0.1$ & 94 \\
\hline \multicolumn{4}{|c|}{$\mathrm{SiG}_{\text {PEI} 1200-1300-L d \mathrm{NDT}}$} \\
\hline $15 \mu \mathrm{g}^{\mathrm{b}}$ & 100 & & \\
\hline $95 \mu g^{b}$ & 97 & $3.0 \pm 0.1$ & 97 \\
\hline $230 \mu \mathrm{g} b$ & 83 & & \\
\hline $470 \mu g^{b}$ & 50 & & \\
\hline \multicolumn{4}{|c|}{$\mathrm{SiG}_{\mathrm{PEI} 25000-L d \mathrm{NDT}}$} \\
\hline $15 \mu g^{b}$ & 99 & & \\
\hline $95 \mu \mathrm{g} b$ & 97 & $3.0 \pm 0.1$ & 97 \\
\hline $230 \mu \mathrm{g}$ & 88 & & \\
\hline $470 \mu g^{b}$ & 55 & & \\
\hline \multicolumn{4}{|c|}{$\mathrm{SiG}_{\text {PEI70000}}-L d \mathrm{NDT}$} \\
\hline $15 \mu g^{b}$ & 98 & & \\
\hline $95 \mu g^{b}$ & 97 & $3.0 \pm 0.1$ & 97 \\
\hline $230 \mu \mathrm{g}$ & 81 & & \\
\hline $470 \mu \mathrm{g}^{\mathrm{b}}$ & 50 & & \\
\hline
\end{tabular}




\subsection{Optimization of Reaction Parameters}

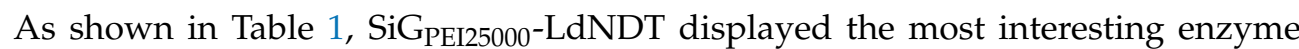
load/activity ratio, so we selected the derivative SiGPEI25000-LdNDT obtained using $230 \mu \mathrm{g}$ of initial protein, for further experimental studies. To evaluate the effect of $\mathrm{pH}$ and temperature on the reaction time course, different experimental conditions were assayed (Figure 3).

A

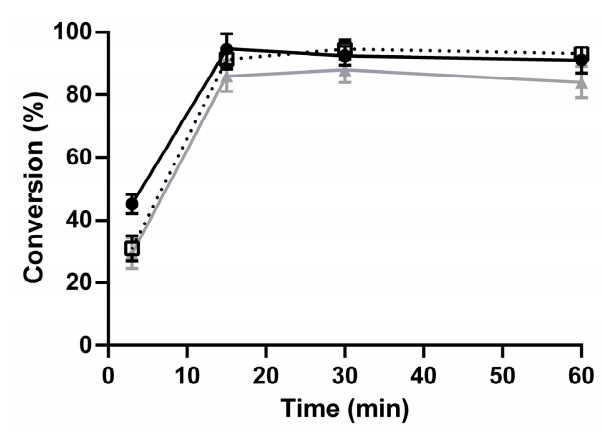

B

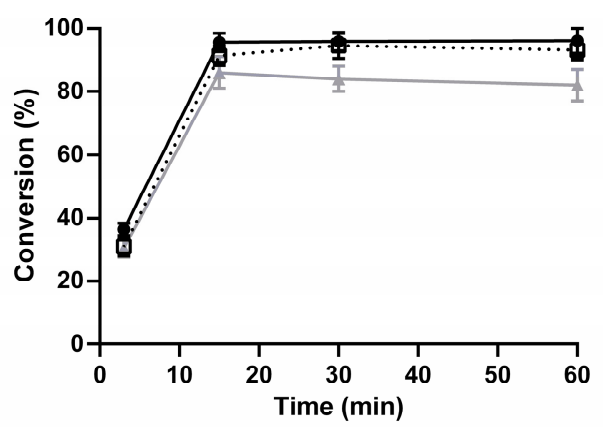

Figure 3. Study of several parameters using SiGPEI25000- $L d$ NDT derivative for cladribine biosynthesis. (A) Effect of $\mathrm{pH}$ on reaction time course, ( $\square) 25 \mathrm{mM}$ sodium acetate buffer, $\mathrm{pH} 5.0$; (•) $25 \mathrm{mM}$ tris- $\mathrm{HCl}$

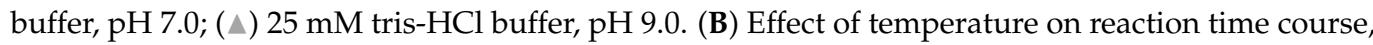
$(\bullet) 30{ }^{\circ} \mathrm{C},(\square) 50^{\circ} \mathrm{C}$, and $(\Delta) 60^{\circ} \mathrm{C}$.

According to the obtained results, neutral and low-acid $\mathrm{pH}$ values were shown to be the most promising experimental conditions ( $>90 \%$ conversion), whereas SiG $L d$ NDT displayed an optimal conversion rate in the temperature range from 30 to $50{ }^{\circ} \mathrm{C}$. These results were similar to those previously observed for soluble protein [30].

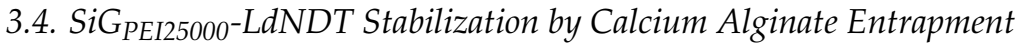

Among natural matrixes, sodium alginate is considered an efficient option for enzyme immobilization because it is nontoxic, hydrophilic, biodegradable, and biocompatible [53]. It has also been demonstrated that calcium alginate entrapment significantly improves enzyme stability and allows easy recovery and reuse of the biocatalyst, favoring a subsequent bioprocess scale-up.

With the aim of optimizing the biocatalyst for future scale-up studies, $\mathrm{SiG}_{\mathrm{PEI}}$ 25000$L d$ NDT derivative was successfully entrapped in calcium alginate to obtain SiGPEI25000LdNDT-Alg biocatalyst $[29,54-56]$. The double stabilized biocatalyst was able to achieve $86 \%$ of cladribine conversion at $15 \mathrm{~min}$, while after $30 \mathrm{~min}$ of reaction a conversion of $96 \%$ was achieved, equaling that achieved by its counterpart without trapping. As expected, the biosynthetic rate of the entrapped biocatalyst decreased slightly, probably due to diffusion restrictions associated with the alginate coating [54-56].

\subsubsection{Temperature and $\mathrm{pH}$ Stability}

To determine the effect of alginate coating on biocatalysts stability, the effect of tem-

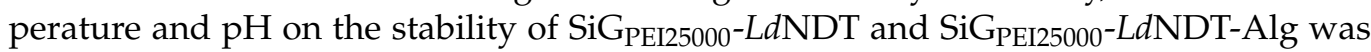
assayed (Figure 4). As shown SiGPEI 25000-LdNDT displayed excellent stability across a broad range of temperatures, exhibiting high stability at $50{ }^{\circ} \mathrm{C}\left(\mathrm{t}_{1 / 2} \approx 3100 \mathrm{~h}\right)$ and $60{ }^{\circ} \mathrm{C}$ $\left(\mathrm{t}_{1 / 2} \approx 600 \mathrm{~h}\right)$ but also high long-term stability at $30^{\circ} \mathrm{C}(60 \%$ retained activity) for incubation periods of more than $3300 \mathrm{~h}$ (Figure 4A). More interestingly, the alginate entrapped biocatalyst improved the stability of SiGPEI 25000-LdNDT when stored at $50{ }^{\circ} \mathrm{C}\left(\mathrm{t}_{1 / 2} \approx 3300 \mathrm{~h}\right)$ and $60{ }^{\circ} \mathrm{C}\left(\mathrm{t}_{1 / 2} \approx 800 \mathrm{~h}\right)$ and enhanced the above-mentioned high long-term stability at $30^{\circ} \mathrm{C}$ $(\approx 80 \%$ retained activity during $3300 \mathrm{~h})$ (Figure $4 \mathrm{~B}$ ). 


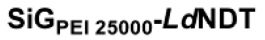

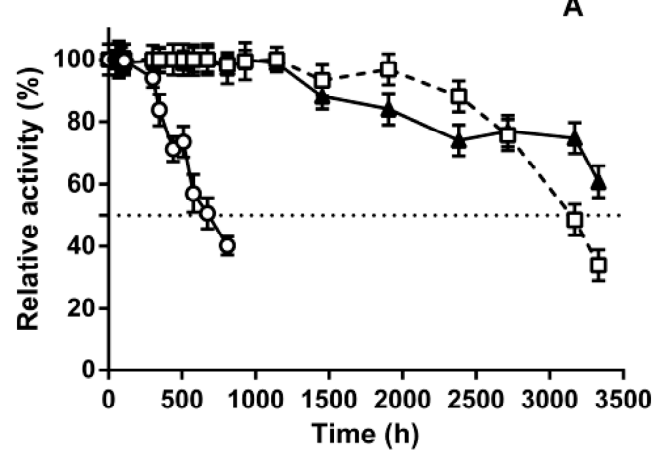

C

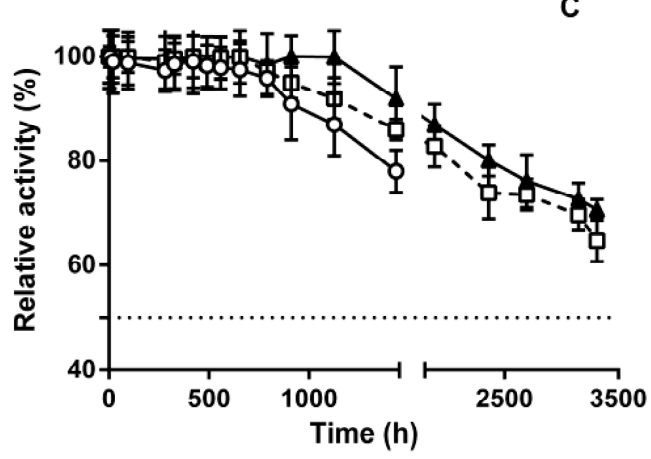

$\mathrm{SiG}_{\mathrm{PEI}} 25000^{-L d N D T-A l g}$

B

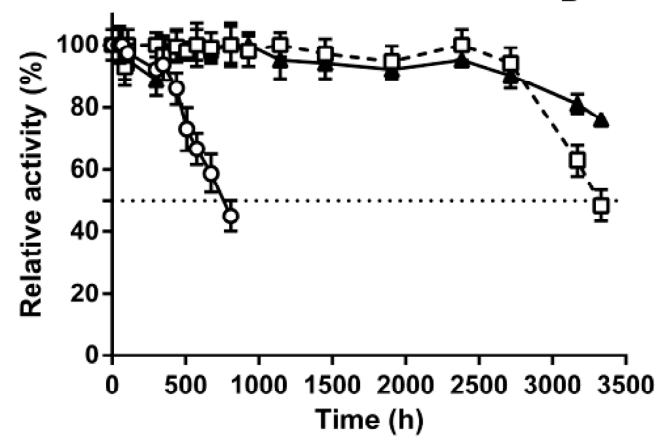

D

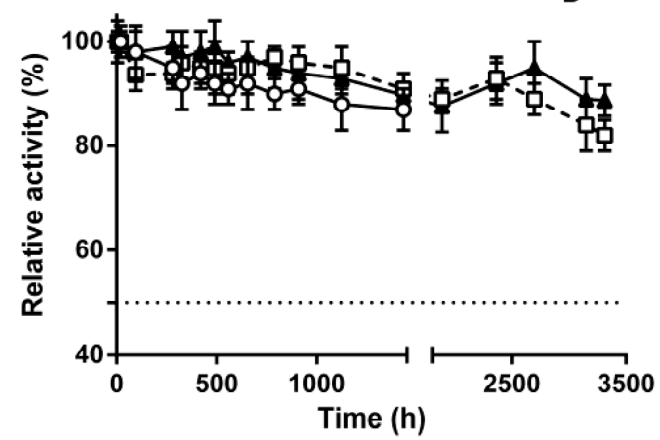

Figure 4. Thermal inactivation of SiGPEI25000- $L d N D T(A)$ and $S_{\text {PiG }} 25000-L d N D T-A l g(\mathbf{B})$ at different temperatures $(\mathbf{\Lambda}) 30^{\circ} \mathrm{C}$,

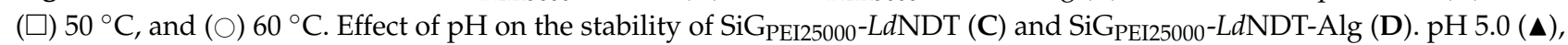
$\mathrm{pH} 7.0(\square)$, and $\mathrm{pH} 9.0(\bigcirc)$.

In a similar way, the obtained biocatalysts, SiGPEI25000- $L d \mathrm{NDT}$ and $\mathrm{SiG}_{\mathrm{PEI} 25000-L d \mathrm{NDT}-}$ $\mathrm{Alg}$, were also incubated at different $\mathrm{pH}$ values ( $\mathrm{pH} 5.0,7.0$ and 9.0) at $50{ }^{\circ} \mathrm{C}$ (Figure $4 \mathrm{C}, \mathrm{D}$ ), and we could observe a similar tendency than that shown for thermal stability experiments. In this sense, both biocatalysts showed a significant improvement in stability over soluble enzymes (Figure S1), which is an operational added value. Since the primary limiting factor for industrial synthesis of purine nucleoside analogs is the poor solubility of some purine bases in aqueous solutions (e.g., adenine, hypoxanthine, or guanine) [57,58], the excellent operational stability at alkaline $\mathrm{pHs}$ of both derivatives qualifies them as potential biocatalysts for the industrial synthesis of purine nucleoside analogs, such as araA, araG, or ddI [5].

To get a possible explanation about this phenomenon, we evaluated the disposition of $\mathrm{N}$-terminus residues in both, dimeric and hexameric form, concluding that the most probably binding involves three $\mathrm{N}$-terminus of different dimers located in the same axial plane (Figure 5). This three-point union provides not only higher rigidification of $L d N D T$ but also contributes to preventing subunit dissociation in the hexamer, leading to a nonexpected high thermal stability. Moreover, the entrapment into calcium alginate also increased this particularly high stability, probably due to the confinement of SiGPEI25000$L d$ NDT within the support, which contributes to increasingbiocatalyst stability and also protects the derivative from surrounding conditions. 

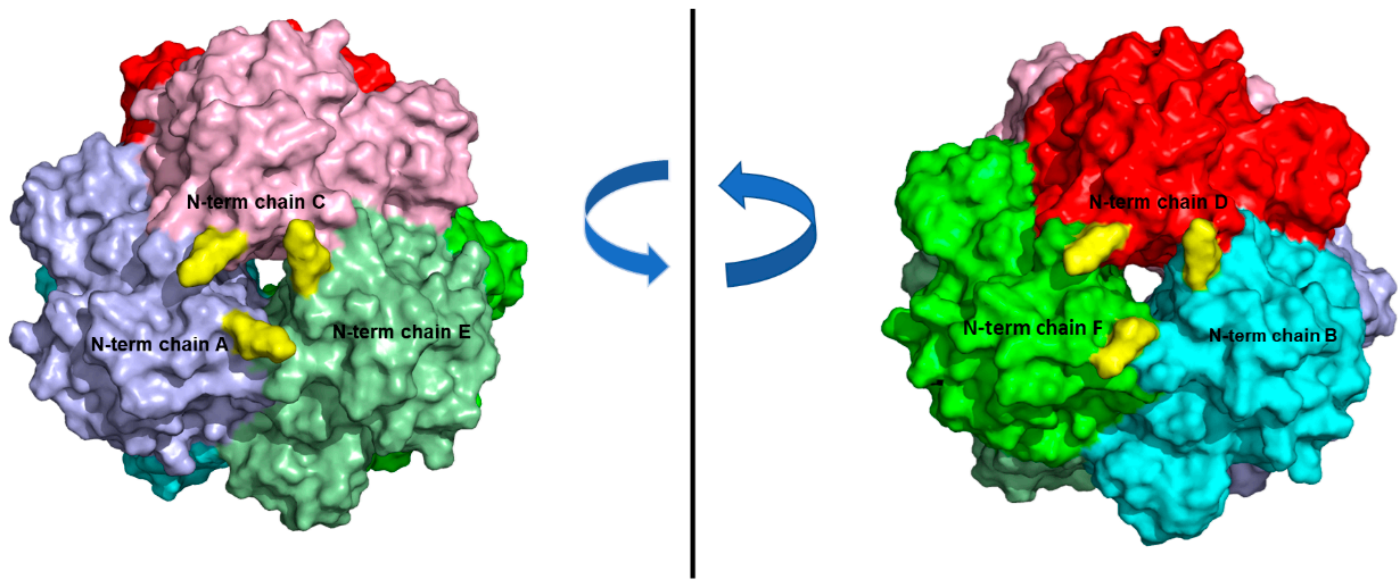

Figure 5. Surface representation of hexamericLdNDT. The different chains (A-F) are highlighted in different colors. Nterminus residues are yellow colored.

\subsubsection{Scanning Electron Microscopy (SEM) Analysis}

The analysis of the morphological characteristics of the SiGPEI25000-LdNDT and SiGPEI25000$L d$ NDT-Alg biocatalysts was performed by SEM (Figure 6). Typical spherical nanoparticles of biomimetic silica, in the $400-800 \mathrm{~nm}$ range were observed (Figure 6A). Glutaraldehyde prompts the formation of randomly agglutinated particles, but these aggregates decrease by the presence of protein, which could reduce the number of free glutaraldehyde molecules [59]. On the other hand, micrographs of SiGPEI25000-LdNDT-Alg show spherical particles $(3 \mathrm{~mm})$ due to the presence of alginate (Figure 6B). Energy dispersive X-ray spectroscopy (EDX) spectra revealed the presence of calcium and chlorine on $\mathrm{SiG}_{\mathrm{PEI} 25000}-\mathrm{LdNDT}-\mathrm{Alg}$, introduced by the calcium alginate matrix (Figure 6C,D).

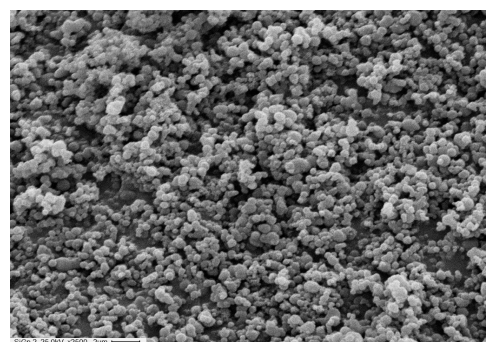

(A)

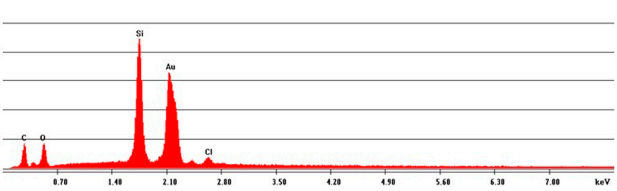

(C)

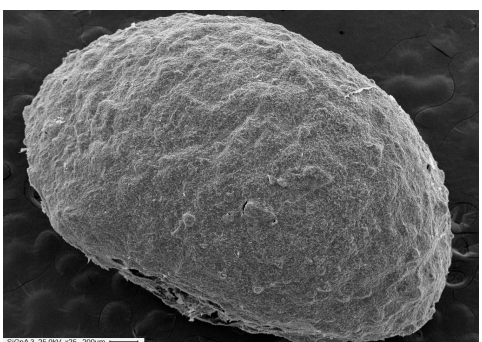

(B)

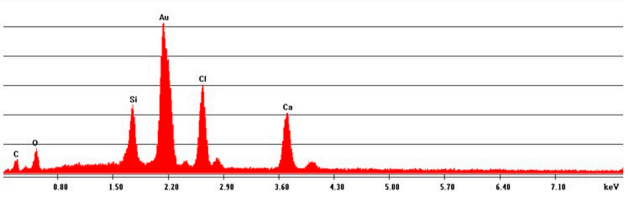

(D)

Figure 6. SEM and EDX analysis of SiGPEI25000-LdNDT $(\mathbf{A}, \mathbf{C})$ and SiGPEI25000-LdNDT-Alg (B,D) biocatalysts.

\subsection{Storage Stability and Reusability of SiGPEI25000-LdNDT and SiGPEI25000-LdNDT-Alg Biocatalysts}

Taking into account the above mentioned results we thought SiGPEI25000-LdNDT and

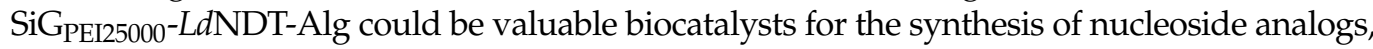
we continued with the characterization of some other operational features, such as storage stability and reusability. Subsequently, storage stability was assayed by keeping the obtained biocatalysts at $4{ }^{\circ} \mathrm{C}$ and determining their activity at different time points (Figure 7A). Both stabilized biocatalysts maintained more than $85 \%$ of their initial activity for at least 10 months (300 days), which is far from the storage stability displayed by soluble $L d \mathrm{NDT}$ when stored at $4{ }^{\circ} \mathrm{C}$ (85\% retained activity after 30 days) [30]. 

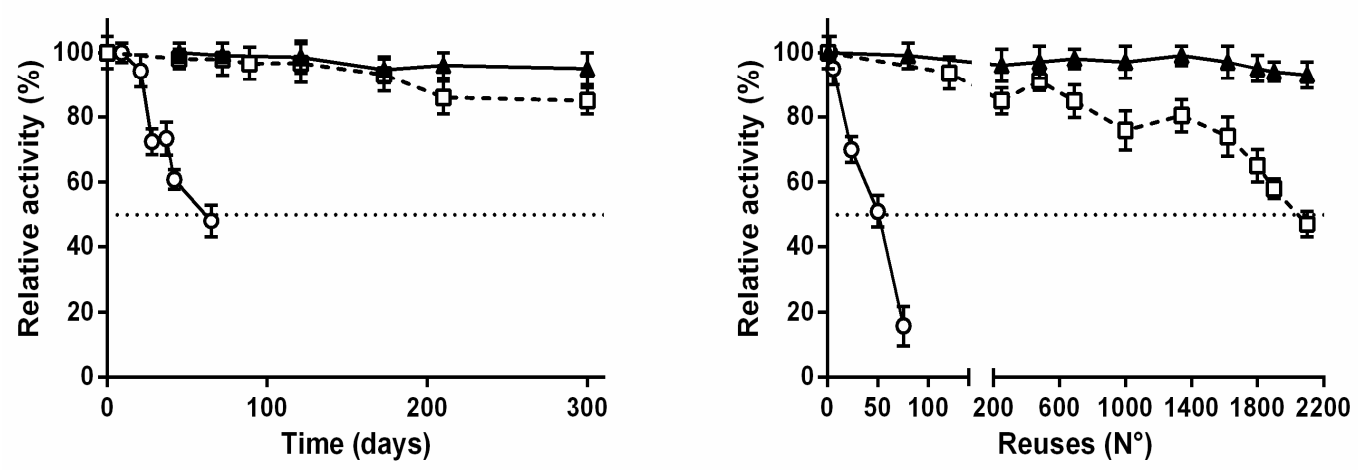

Figure 7. Storage stability at $4{ }^{\circ} \mathrm{C}$ (A) and reusability (B) of (A)SiGPEI25000- $L d N D T-A l g$, ( $\left.\square\right)$ SiGPEI25000-LdNDT, and ( $\bigcirc)$ CNBr-LdNDT.

Biocatalyst recycling is an essential pre-requisite for its industrial application, therefore, both biocatalysts, $\mathrm{SiGPEI}_{25000}-\mathrm{L} d \mathrm{NDT}$ and $\mathrm{SiG}_{\mathrm{PEI}} 5000-\mathrm{L} d \mathrm{NDT}-\mathrm{Alg}$, were employed in consecutive batch reactions (Figure $7 \mathrm{~B}$ ). Both maintained $\geq 50 \%$ retained activity over

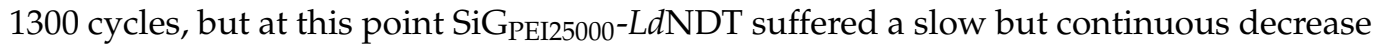
in retained activity. In contrast, $\mathrm{SiG}_{\mathrm{PEI} 25000-L d N D T-A l g}$ was successfully reused up to 2100 cycles with negligible loss of activity, which considerably increased the reusability of alginate-free derivative. These results are lined with those shown for thermal inactivation experiments, which displayed an excellent thermal stability, but also highlight the extremely high operational stability for both derivatives. As suggested above, the entrapment of SiGPEI25000-LdNDT on alginate, led to a higher stabilization of the derivative but also contributed to avoiding the mechanical damage associated withmechanical stirring, which could promote the subunit dissociation and therefore a reduction in biocatalysts' reusability.

Although a high number of NDT-mediated bioprocesses using immobilized biocatalysts have been reported during the last decade $[10,11,29,32,33,38,42,43,45,46,54,55,60,61]$, most of them focused on cladribine synthesis $[11,30,38,45,54,61]$, the low biocatalyst reusability under assay conditions often hinders their industrial implementation. Illustrative examples of this operational problem are cladribine synthesis using PDT from Trypanosoma brucei immobilized (TbPDT) onto glutaraldehyde-activated microparticles (25 reuses without any activity loss, $1 \mathrm{mM}$ substrates, 41\% conversion) [45] or mutant $\mathrm{TbPDT}_{\mathrm{V} 11 \mathrm{~S}}$ immobilized onto $\mathrm{Ni}^{2+}$ chelate magnetic microparticles (10 reuses without any activity loss, $2 \mathrm{mM}$ substrates, $21 \%$ conversion) [61]. This operational problem was also observed for other immobilized enzymes (e.g., cascade synthesis of cladribine using immobilized PNP and PyNP from Geobacillus stearothermophilus; 20 reuses, $5 \mathrm{mM}$ substrates $85 \%$ conversion) [62]. Interestingly, several recent articles have addressed this issue, developing novel immobilized derivatives with high operational stability and reusability, such as Arthrobacter oxydans cells immobilized on alginate ( 20 reuses, $0.5 \mathrm{mM}$ sub-strates, $85 \%$ conversion) [54] or Thermomonospora alba whole cells entrapped in nanostabilized hydrogels (270 reuses, $0.5 \mathrm{mM}$ substrates, $89 \%$ conversion) [38]. However, these experimental results are surmounted by those shown in this work ( 2100 reuses, $1 \mathrm{mM}, \approx 95 \%$ conversion).

\subsection{Bioprocess Scale-Up}

Finally, as a proof of concept, the tentative scale-up of SiGPEI25000-LdNDT-Alg mediated synthesis of cladribine was carried out using a batch system with an airlift column, increasing the biocatalyst amount and reaction medium volume by tenfold. Reaction productivity was not significantly affected in comparison with micro-scale assays, affording $90 \%$ of reaction yield at $30 \mathrm{~min}$, allowing us to obtain $2.6 \mathrm{mg}$ of product per hour as evaluated by HPLC. Therefore, considering its demonstrated reuse capacity, this combined biocatalyst could produce $1.8 \mathrm{~g}$ of cladribine, forty times more than that required per 
treatment cycle for an average patient $(44 \mathrm{mg})$, using a dosing regimen of $0.09 \mathrm{mg} / \mathrm{kg}$ Q7D43.

Additionally, several green parameters such as E-factor, C-efficiency, and A-economy were calculated for the proposed bioprocess (Table 2).

Table 2. Scale-up bioprocess for cladribine biosynthesis using a batch bioreactor. Environmental factors were calculated as previously reported $[38,63]$.

\begin{tabular}{cccc}
\hline Specific Productivity $^{\text {a }}$ & E-Factor & C-Efficiency & A-Economy \\
\hline 8.6 & 1.6 & 67 & 69 \\
\hline${ }^{a}$ Cladribine $(\mathrm{mg} / \mathrm{h}) /$ g catalyst. & &
\end{tabular}

In this way, the E-Factor value for cladribine biotransformation was $<2$, suggesting mass utilization efficiency and a significant decrease inwaste production. Furthermore, C-Efficiency and A-Economy are parameters used to evaluate the efficiency of synthetic reactions, showing a positive effect on atom recovery and bioprocess efficiency [64].

\section{Conclusions}

Herein we report, for the first time, the immobilization of LdNDT onto different supports. Among resulting immobilized derivatives, SiGPEI25000-LdNDT was selected as the optimal biocatalyst for further biochemical studies. With the aim to obtain a highly stable derivative, SiGPEI25000- $L d$ NDT was also entrapped in calcium alginate, leading to a

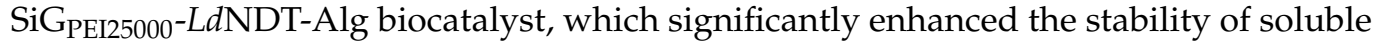
LdNDT, but also widely outperformed the thermal stability and reusability of SiGPEI25000$L d$ NDT derivative.

Finally, the scale-up of cladribine biosynthesis by the developed biocatalyst; SiGPEI25000LdNDT-Alg, was achieved. Thus, an environmentally friendly process which displays an excellent stability, reusability, and high productivity for low cost cladribine biosynthesis using a novel double stabilized NDT biocatalyst, was developed.

Supplementary Materials: The following are available online at https://www.mdpi.com/article/10 .3390/biom11050657/s1, Figure S1: Thermal inactivation and pH effect on stability of soluble LdNDT, Table S1: Computed pKa values of the surface exposed lysine residues in LdNDT using the H++ server (http:/ / biophysics.cs.vt.edu/H++, accessed on 24 March 2021).

Author Contributions: Conceptualization, C.W.R., N.S.G., J.F.-L., L.B.,and J.A.T.; formal analysis, C.W.R., N.S.G., J.F.-L., L.B., G.P.R., and J.A.T.; funding acquisition, C.W.R. and J.A.T.; investigation, C.W.R. and N.S.G.; methodology, C.W.R., J.F.-L., L.B., and J.A.T.; resources, C.W.R., J.F.-L., G.P.R., and J.A.T.; software, C.W.R., J.F.-L., and G.P.R.; supervision, C.W.R. and J.A.T.; visualization, C.W.R. and J.F.-L.; writing-original draft, C.W.R., N.S.G., and J.F.-L.; writing-review \& editing, L.B., G.P.R., and J.A.T. All authors have read and agreed to the published version of the manuscript.

Funding: This research was mainly supported by Agencia Nacional de Pro-mociónCientífica y Tecnológica (PICT 2014-3438), Consejo Nacional de InvestigacionesCientíficas y Técnicas (PIP 2014- 11220130100805CO) and Universidad Nacional de Quilmes (PUNQ 1305/19, PPROF 2017EXPTE.895/18) (to C.W.R. and J.T.). This work was also supported by grants XSAN192006 from the Santander Foundation and 2020/UEM42 from the European University of Madrid (to J.F.L.).

Institutional Review Board Statement: Not applicable.

Informed Consent Statement: Not applicable.

Data Availability Statement: Not applicable.

Acknowledgments: C.W.R. and J.A.T. are research members of CONICET. G.P.R. appreciates the financial support of CONICET and the National University of La Plata (UNLP). We are grateful to Javier Acosta and Eliana C. De Benedetti for their collaboration in some experimental works.

Conflicts of Interest: The authors declare no conflict of interest. 


\section{References}

1. Spurgeon, S.; Yu, M.; Phillips, J.D.; Epner, E.M. Cladribine: Not just another purine analogue? Expert Opin. Investig. Drugs 2002, 18, 1169-1181. [CrossRef] [PubMed]

2. Biernacki, T.; Sandi, D.; Bencsik, K.; Vécsei, L. Medicinal chemistry of multiple sclerosis: Focus on cladribine. Mini Rev. Med. Chem. 2020, 20, 269-285. [CrossRef] [PubMed]

3. Peng, Y. A practical synthesis of 2-chloro-2'-deoxyadenosine (cladribine) from 2'-deoxyadenosine. J. Chem. Res. 2013, 37, 213-215. [CrossRef]

4. Fernández-Lucas, J.; Camarasa, M.J. (Eds.) Enzymatic and Chemical Synthesis of Nucleic Acid Derivatives; John Wiley \& Sons: Hoboken, NJ, USA, 2019. [CrossRef]

5. Lapponi, M.J.; Rivero, C.W.; Zinni, M.A.; Britos, C.N.; Trelles, J.A. New developments in nucleoside analogues biosynthesis: A review. J. Mol. Catal. B Enzym. 2016, 133, 218-233. [CrossRef]

6. Fresco-Taboada, A.; de La Mata, I.; Arroyo, M.; Fernández-Lucas, J. New insights on nucleoside 2'-deoxyribosyltransferases: A versatile biocatalyst for one-pot one-step synthesis of nucleoside analogs. Appl. Microbiol. Biotechnol. 2013, 97, $3773-3785$. [CrossRef]

7. Del Arco, J.; Acosta, J.; Fernández-Lucas, J. New trends in the biocatalytic production of nucleosidic active pharmaceutical ingredients using 2'-deoxyribosyltransferases. Biotechnol. Adv. 2021, 107701. [CrossRef]

8. Mikhailopulo, I.A.; Miroshnikov, A.I. Biologically important nucleosides: Modern trends in biotechnology and application. Mendeleev Commun. 2011, 21, 57-69. [CrossRef]

9. Yehia, H.; Kamel, S.; Paulick, K.; Neubauer, P.; Wagner, A. Substrate spectra of nucleoside phosphorylases and their potential in the production of pharmaceutically active compounds. Curr. Pharm. Des. 2017, 23, 6913-6935. [CrossRef]

10. Méndez, M.B.; Rivero, C.W.; López-Gallego, F.; Guisán, J.M.; Trelles, J.A. Development of a high efficient biocatalyst by oriented covalent immobilization of a novel recombinant 2'-N-deoxyribosyltransferase from Lactobacillus animalis. J. Biotechnol. 2018, 270, 39-43. [CrossRef]

11. Britos, C.N.; Lapponi, M.J.; Cappa, V.A.; Rivero, C.W.; Trelles, J.A. Biotransformation of halogenated nucleosides by immobilized Lactobacillus animalis 2'-N-deoxyribosyltransferase. J. Fluor. Chem. 2016, 186, 91-96. [CrossRef]

12. Drenichev, M.S.; Alexeev, C.S.; Kurochkin, N.N.; Mikhailov, S.N. Use of nucleoside phosphorylases for the preparation of purine and pyrimidine 2'-deoxynucleosides. Adv. Synth. Catal. 2018, 360, 305-312. [CrossRef]

13. Liu, G.; Cheng, T.; Chu, J.; Li, S.; He, B. Efficient synthesis of purine nucleoside analogs by a new trimeric purine nucleoside phosphorylase from Aneurinibacillusmigulanus AM007. Molecules 2020, 25, 100. [CrossRef] [PubMed]

14. Rabuffetti, M.; Bavaro, T.; Semproli, R.; Cattaneo, G.; Massone, M.; Morelli, C.F.; Speranza, G.; Ubiali, D. Synthesis of ribavirin, tecadenoson, and cladribine by enzymatic transglycosylation. Catalysts 2019, 9, 355. [CrossRef]

15. Zhou, X.; Szeker, K.; Jiao, L.Y.; Oestreich, M.; Mikhailopulo, I.A.; Neubauer, P. Synthesis of 2,6-dihalogenated purine nucleosides by thermostable nucleoside phosphorylases. Adv. Synth. Catal. 2015, 357, 1237-1244. [CrossRef]

16. Sheldon, R.A.; van Pelt, S. Enzyme immobilization in biocatalysis: Why, what and how. Chem. Soc. Rev. 2013, $42,6223-6235$. [CrossRef]

17. Mateo, C.; Palomo, J.M.; Fernandez-Lorente, G.; Guisan, J.M.; Fernández-Lafuente, R. Improvement of enzyme activity, stability and selectivity via immobilization techniques. Enzyme Microb. Technol. 2007, 40, 1451-1463. [CrossRef]

18. Barbosa, O.; Torres, R.; Ortiz, C.; Berenguer-Murcia, A.; Rodrigues, R.C.; Fernandez-Lafuente, R. Heterofunctional supports in enzyme immobilization: From traditional immobilization protocols to opportunities in tuning enzyme properties. Biomacromolecules 2013, 14, 2433-2462. [CrossRef]

19. Rodrigues, R.C.; Ortiz, C.; Berenguer-Murcia, Á.; Torres, R.; Fernández-Lafuente, R. Modifying enzyme activity and selectivity by immobilization. Chem. Soc. Rev. 2013, 42, 6290-6307. [CrossRef]

20. Guisan, J.M.; Lopez-Gallego, F.; Bolivar, J.M.; Rocha-Martín, J.; Fernandez-Lorente, G. The science of enzyme immobilization. In Immobilization of Enzymes and Cells; Humana Press: Totowa, NJ, USA, 2020; pp. 1-26. [CrossRef]

21. Rimola, A.; Costa, D.; Sodupe, M.; Lambert, J.F.; Ugliengo, P. Silica surface features and their role in the adsorption of biomolecules: Computational modeling and experiments. Chem. Rev. 2013, 113, 4216-4313. [CrossRef]

22. Zucca, P.; Sanjust, E. Inorganic materials as supports for covalent enzyme immobilization: Methods and mechanisms. Molecules 2014, 19, 14139-14194. [CrossRef]

23. Luckarift, H.R.; Spain, J.C.; Naik, R.R.; Stone, M.O. Enzyme immobilization in a biomimetic silica support. Nat. Biotechnol. 2004, 22, 211-213. [CrossRef] [PubMed]

24. Coradin, T.; Lopez, P.J.; Gautier, C.; Livage, J. From biogenic to biomimetic silica. C. R. Palevol 2004, 3, 443-452. [CrossRef]

25. Sumper, M.; Brunner, E. Silica biomineralisation in diatoms: The model organism Thalassiosirapseudonana. ChemBioChem 2008, 9 , 1187-1194. [CrossRef]

26. Lechner, C.C.; Becker, C.F.W. Silaffins in silica biomineralization and biomimetic silica precipitation. Mar. Drugs 2015, 13, 5297-5333. [CrossRef]

27. Lee, K.Y.; Mooney, D.J. Alginate: Properties, biomedical applications. Prog. Polym. Sci. 2012, 37, 106-126. [CrossRef] [PubMed]

28. Funami, T.; Fang, T.; Noda, S.; Ishihara, S.; Nakauma, M.; Draget, K.I.; Nishinari, K.; Phillips, G.O. Rheological properties of sodium alginate in an aqueous system during gelation in relation to supermolecular structures and $\mathrm{Ca}^{2+}$ binding. Food Hydrocoll. 2009, 23, 1746-1755. [CrossRef] 
29. Cappa, V.A.; Rivero, C.W.; Britos, C.N.; Martinez, L.M.; Lozano, M.E.; Trelles, J.A. An efficient biocatalytic system for floxuridine biosynthesis based on Lactobacillus animalis ATCC 35046 immobilized in Sr-alginate. Process.Biochem. 2014, 49, 1169-1175. [CrossRef]

30. Acosta, J.; del Arco, J.; Martinez-Pascual, S.; Clemente-Suárez, V.J.; Fernández-Lucas, J. One-pot multi-enzymatic production of purine derivatives with application in pharmaceutical and food industry. Catalysts 2018, 8, 9. [CrossRef]

31. Acosta, J.; Pérez, E.; Sánchez-Murcia, P.A.; Fillat, C.; Fernández-Lucas, J. Molecular basis of NDT-mediated activation of nucleoside-based prodrugs and application in suicide gene therapy. Biomolecules 2021, 11, 120. [CrossRef]

32. Cazaban, D.; Illanes, A.; Wilson, L.; Betancor, L. Bio-inspired silica lipase nanobiocatalysts for the synthesis of fatty acid methyl esters. Process Biochem. 2018, 74, 86-93. [CrossRef]

33. Trelles, J.A.; Rivero, C.W. Whole cell entrapment techniques. In Immobilization of Enzymes and Cells; Humana Press: Totowa, NJ, USA, 2020; pp. 385-394. [CrossRef]

34. Delano, W.L. The PyMOL Molecular Graphics System; DeLano Scientific: Palo Alto, CA, USA, 2002.

35. Acosta, J.; del Arco, J.; Pisabarro, V.; Gago, F.; Fernández-Lucas, J. N-ribosyltransferase from Archaeoglobusveneficus: A novel halotolerant and thermostable biocatalyst for the synthesis of purine ribonucleoside analogs. Front. Bioeng. Biotechnol. 2020, 8 , 593. [CrossRef] [PubMed]

36. Acosta, J.; del Arco, J.; del Pozo, M.L.; Herrera-Tapias, B.; Clemente-Suárez, V.J.; Berenguer, J.; Hidalgo, A.; Fernández-Lucas, J. Hypoxanthine-guanine phosphoribosyltransferase/adenylate kinase from Zobelliagalactanivorans: A bifunctional catalyst for the synthesis of nucleoside-5-mono-, di-and triphosphates. Front. Bioeng. Biotechnol. 2020, 8, 677. [CrossRef] [PubMed]

37. Roe, D.R.; Cheatham, T.E., III. PTRAJ and CPPTRAJ: Software for processing and analysis of molecular dynamics trajectory data. J. Chem. Theory Comput. 2013, 9, 3084-3095. [CrossRef] [PubMed]

38. Rivero, C.W.; de Benedetti, E.C.; Sambeth, J.; Trelles, J.A. Biotransformation of cladribine by a nanostabilized extremophilic biocatalyst. J. Biotechnol. 2020, 323, 166-173. [CrossRef] [PubMed]

39. Zucca, P.; Fernandez-Lafuente, R.; Sanjust, E. Agarose and its derivatives as supports for enzyme immobilization. Molecules 2016, 21, 1577. [CrossRef]

40. Betancor, L.; Luckarift, H.R. Bioinspired enzyme encapsulation for biocatalysis. Trends Biotechnol. 2008, 26, 566-572. [CrossRef] [PubMed]

41. Jackson, E.; Correa, S.; Betancor, L. In situ immobilization of enzymes in biomimetic silica. In Immobilization of Enzymes and Cells; Humana Press: Totowa, NJ, USA, 2020; pp. 259-270. [CrossRef]

42. Fresco-Taboada, A.; Serra, I.; Fernández-Lucas, J.; Acebal, C.; Arroyo, M.; Terreni, M.; de la Mata, I. Nucleoside 2'deoxyribosyltransferase from psychrophilic bacterium Bacillus psychrosaccharolyticus_-Preparation of an immobilized biocatalyst for the enzymatic synthesis of therapeutic nucleosides. Molecules 2014, 19, 11231-11249. [CrossRef]

43. Fresco-Taboada, A.; Serra, I.; Arroyo, M.; Fernández-Lucas, J.; de la Mata, I.; Terreni, M. Development of an immobilized biocatalyst based on Bacillus psychrosaccharolyticus NDT for the preparative synthesis of trifluridine and decytabine. Catal. Today 2016, 259, 197-204. [CrossRef]

44. Barbosa, O.; Ortiz, C.; Berenguer-Murcia, Á.; Torres, R.; Rodrigues, R.C.; Fernandez-Lafuente, R. Glutaraldehyde in biocatalysts design: A useful crosslinker and a versatile tool in enzyme immobilization. RSC Adv. 2014, 4, 1583-1600. [CrossRef]

45. Pérez, E.; Sánchez-Murcia, P.A.; Jordaan, J.; Blanco, M.D.; Mancheño, J.M.; Gago, F.; Fernández-Lucas, J. Enzymatic synthesis of therapeutic nucleosides using a highly versatile purine nucleoside 2'-deoxyribosyltransferase from Trypanosoma brucei. ChemCatChem 2018, 10, 4406-4416. [CrossRef]

46. Fernández-Lucas, J.; Harris, R.; Mata-Casar, I.; Heras, A.; de la Mata, I.; Arroyo, M. Magnetic chitosan beads for covalent immobilization of nucleoside 2'-deoxyribosyltransferase: Application in nucleoside analogues synthesis. J. Ind. Microbiol. Biotechnol. 2013, 40, 955-966. [CrossRef]

47. Virgen-Ortíz, J.J.; Dos Santos, J.C.; Berenguer-Murcia, Á.; Barbosa, O.; Rodrigues, R.C.; Fernandez-Lafuente, R. Polyethylenimine: A very useful ionic polymer in the design of immobilized enzyme biocatalysts. J. Mater. Chem. B 2017, 5, 7461-7490. [CrossRef]

48. Rivero, C.W.; de Benedetti, E.C.; López Gallego, F.; Pessela, B.C.; Guisán, J.M.; Trelles, J.A. Biosynthesis of an antiviral compound using a stabilized phosphopentomutase by multipoint covalent immobilization. J. Biotechnol. 2017, 249, 34-41. [CrossRef]

49. Del Arco, J.; Pérez, E.; Naitow, H.; Matsuura, Y.; Kunishima, N.; Fernández-Lucas, J. Structural and functional characterization of thermostable biocatalysts for the synthesis of 6-aminopurine nucleoside-5'-monophospate analogues. Bioresour. Technol. 2019, 276, 244-252. [CrossRef]

50. Del Arco, J.; Martínez-Pascual, S.; Clemente-Suárez, V.J.; Corral, O.J.; Jordaan, J.; Hormigo, D.; Perona, A.; Fernández-Lucas, J. One-pot, one-step production of dietary nucleotides by magnetic biocatalysts. Catalysts 2018, 8, 184. [CrossRef]

51. Del Arco, J.; Galindo, J.; Clemente-Suárez, V.J.; Corrales, A.; Fernández-Lucas, J. Sustainable synthesis of uridine-5'monophosphate analogues by immobilized uracil phosphoribosyltransferase from Thermus thermophilus. Biochim. Biophys. Acta 2020, 1868, 140251. [CrossRef] [PubMed]

52. Notley, S.M.; Leong, Y.K. Interaction between silica in the presence of adsorbed poly(ethyleneimine): Correlation between colloidal probe adhesion measurements and yield stress. Phys. Chem. Chem. Phys. 2010, 12, 10594-10601. [CrossRef]

53. Iliescu, R.I.; Andronescu, E.; Voicu, G.; Ficai, A.; Covaliu, C.I. Hybrid materials based on montmorillonite and citostatic drugs: Preparation and characterization. Appl. Clay Sci. 2011, 52, 62-68. [CrossRef] 
54. Lapponi, M.J.; Britos, C.N.; Rivero, C.W.; Trelles, J.A. Biotransformation of cladribine using a stabilized biocatalyst in calcium alginate beads. Biotechnol. Progr. 2020, 36, e2927. [CrossRef] [PubMed]

55. Fernández-Lucas, J.; Condezo, L.A.; Quezada, M.A.; Sinisterra, J.V. Low-temperature synthesis of 2'-deoxyadenosine using immobilized psychrotrophic microorganisms. Biotechnol. Bioengineer. 2008, 100, 213-222. [CrossRef] [PubMed]

56. Fernández-Lucas, J.; Condezo, L.A.; Martinez-Lagos, F.; Sinisterra, J.V.; Biotransformation Group. Synthesis of 2'deoxyibosylnucleosides using new 2'-deoxyribosyltransferase microorganism producers. Enzym. Microbial. Technol. 2007, 40, 1147-1155. [CrossRef]

57. Crespo, N.; Sánchez-Murcia, P.A.; Gago, F.; Cejudo-Sanches, J.; Galmes, M.A.; Fernández-Lucas, J.; Mancheño, J.M. 2'Deoxyribosyltransferase from Leishmania mexicana, an efficient biocatalyst for one-pot, one-step synthesis of nucleosides from poorly soluble purine bases. Appl. Microbiol. Biotechnol. 2017, 101, 7187-7200. [CrossRef]

58. Del Arco, J.; Cejudo-Sanches, J.; Esteban, I.; Clemente-Suárez, V.J.; Hormigo, D.; Perona, A.; Fernández-Lucas, J. Enzymatic production of dietary nucleotides from low-soluble purine bases by an efficient, thermostable and alkali-tolerant biocatalyst. Food Chem. 2017, 237, 605-611. [CrossRef]

59. Jackson, E.; Ferrari, M.; Cuestas-Ayllon, C.; Fernández-Pacheco, R.; Perez-Carvajal, J.; de la Fuente, J.M.; Grazú, V.; Betancor, L. Protein-templated biomimetic silica nanoparticles. Langmuir 2015, 31, 3687-3695. [CrossRef]

60. Rinaldi, F.; Fernández-Lucas, J.; de la Fuente, D.; Zheng, C.; Bavaro, T.; Peters, B.; Massolini, G.; Annunziata, F.; Conti, P.; de la Mata, I.; et al. Immobilized enzyme reactors based on nucleoside phosphorylases and 2'-deoxyribosyltransferase for the in-flow synthesis of pharmaceutically relevant nucleoside ana-logues. Bioresour. Technol. 2020, 307, 123258. [CrossRef]

61. Del Arco, J.; Jordaan, J.; Moral-Dardé, V.; Fernández-Lucas, J. Sustainable production of nucleoside analogues by a high-efficient purine 2'-deoxyribosyltransferase immobilized onto $\mathrm{Ni}^{2+}$ chelate magnetic microparticles. Bioresour. Technol. 2019, $289,121772$. [CrossRef] [PubMed]

62. Taran, S.A.; Verevkina, K.N.; Feofanov, S.A.; Miroshnikov, A.I. Enzymatic transglycosylation of natural and modified nucleosides by immobilized thermostable nucleoside phosphorylases from Geobacillus stearothermophilus. Russ. J. Bioorganic Chem. 2009, 35 , 739-745. [CrossRef] [PubMed]

63. De Benedetti, E.C.; Rivero, C.W.; Britos, C.N.; Lozano, M.E.; Trelles, J.A. Biotransformation of 2,6-diaminopurine nucleosides by immobilized Geobacillus stearothermophilus. Biotechnol. Progr. 2012, 28, 1251-1256. [CrossRef] [PubMed]

64. Sheldon, R.A. Green chemistry and resource efficiency: Towards a green economy. Green Chem. 2016, 18, 3180-3183. [CrossRef] 